\title{
AN ASSESSMENT OF STRUCTURAL TRAPS IN RELATION TO STRESS PATTERNS IN CHAD BASIN
}

OKPIKORO E. FREEBORN

\begin{abstract}
The interpretation of 2-D seismic reflection time sections from Doili area of the Chad Basin (N.E. Nigeria) indicates two genetic stratigraphic units separated by an unconformity surface. Post-depositional structural deformation of seismic horizons above the unconformity plane is minimal, while that of seismic horizons below it is intense, resulting in a series of faults (normal and reverse) and folds. In this study, the stress conditions that resulted in the formation of these structural trapping elements are examined. This is to assess their capabilities for petroleum entrapment/retention. The normal faults generally have steep gradient planes, originate within the basement rocks and terminate below the unconformity surface. These faults are due mainly to tensional stress directed in opposing directions of northwest and southeast, away from the main axis of Benue Trough-Chad Basin (northeast - southwest). Generally, fault systems due to tensional stresses leave the fault planes as open fractures, hence imperfect seals. The reverse faults most often are closely associated with the folds (anticlines). They resulted from underthrusting of the Cretaceous strata by igneous intrusives that are randomly distributed within the basin. The resultant effects of the late Cretaceous igneous intrusions are arching/folding of the overlying strata, and reverse faults with steep gradient planes. The associated heat could lead to degradation of accumulated petroleum, while the thrusting could create new avenues for remigration. Structural deformation by compressional stress is very minimal in this area. This is evidenced by a general lack of low angle normal faults, strike-slip faults, and well defined regional patterns of the fold systems. Thus the capabilities of these structural elements when examined in relation to hydrocarbon entrapment leave no cile in doubt that there is a high risk of drilling dry holes if solely considered in prospects
\end{abstract}

KEY WORDS: Tensional stress, normal fault, magmatic intrusion, fold, reverse fault.

\section{INTRODUCTION}

The Chad Basin is an intracontinential rift basin, which extends from N.E. Nigeria to Chad Republic, Niger Republic and Cameroon within latitudes $10^{\circ} \mathrm{N}$ to $14^{\circ} \mathrm{N}$ and longitudes $12^{\circ} \mathrm{E}$ to $15^{\circ} \mathrm{E}$ (Figure 1). The basin had been investigated at various times by different workers to assess its hydrocarbon potentials. Agagu and Ekweozor (1980) evaluated the area for hydrocarbon traps and concluded that the basal and interfingering sandstones in the basin are among potential hydrocarbon traps. Petters and Ekweozor (1982) analysed shale samples (ranging in age from Albian to Eocene) from southern part of the basin for "Total organic carbon content" and reported a value of over $0.5 \%$. They inferred that the hish terrigeneous character of the marine Fikd shale evident in their low n-alkane ratio indicated that mainly wet gas might have been generated and that the marine facies of Fika Shale could have generated liquid hydrocarbon.

Avbovbo et al. (1986) investigated the depositional and structural styles and concluded that the various normal and reverse faults could be structural traps. Although data on paleotemperature and geothermal gradients are not available for the Chad Basin, comparative studies in the neighbouring petroleum producing basins namely the Niger Delta and Duala Basins (Ekweozor and Okoye, 1980; Albrecht and Ourission, 1969) show that the peak generation zone in the Chad Basin is located well below $2,000 \mathrm{~m}$ from the prosent surfaces. Despite these various parameters analysed favouring high hydrocarbon prospect of the Nigerian sector of the basin, however, about 50 exploratory wells drilled up to date by the Nigerian National Petroleum Corporation (NNPC) had been found to contain noncommercial quantities of petroleum. The exploration activity by NNPC is further spurred by the reported discoveries of commercial quantities of crude oil in neighbouring Chad and Niger Republics, which commonly share the basin.

In this work, seismic evidence of postdepositional structural deformation and its implication on hydrocarbon prospect is investigated. This is hoped to provide answers to the following 
(i) How effective are the fault planes of both normal and reverse faults abundant in the basin as structural traps/seals?

(ii) Is the structural folding of the sediments due mainly to compressional stress or magmatic intrusive?

(iii) If folding of strata was due to magmatic activities, what effect does it have on already accumulated hydrocarbon?
Solutions to the above questions will provide scientific basis for further evaluation of the hydrocarbon prospect of the basin. It could also be used for correlation with neighbouring producing fields of Chad and Niger Republics to establish continuity/uniformity of conditions in the entire basin.

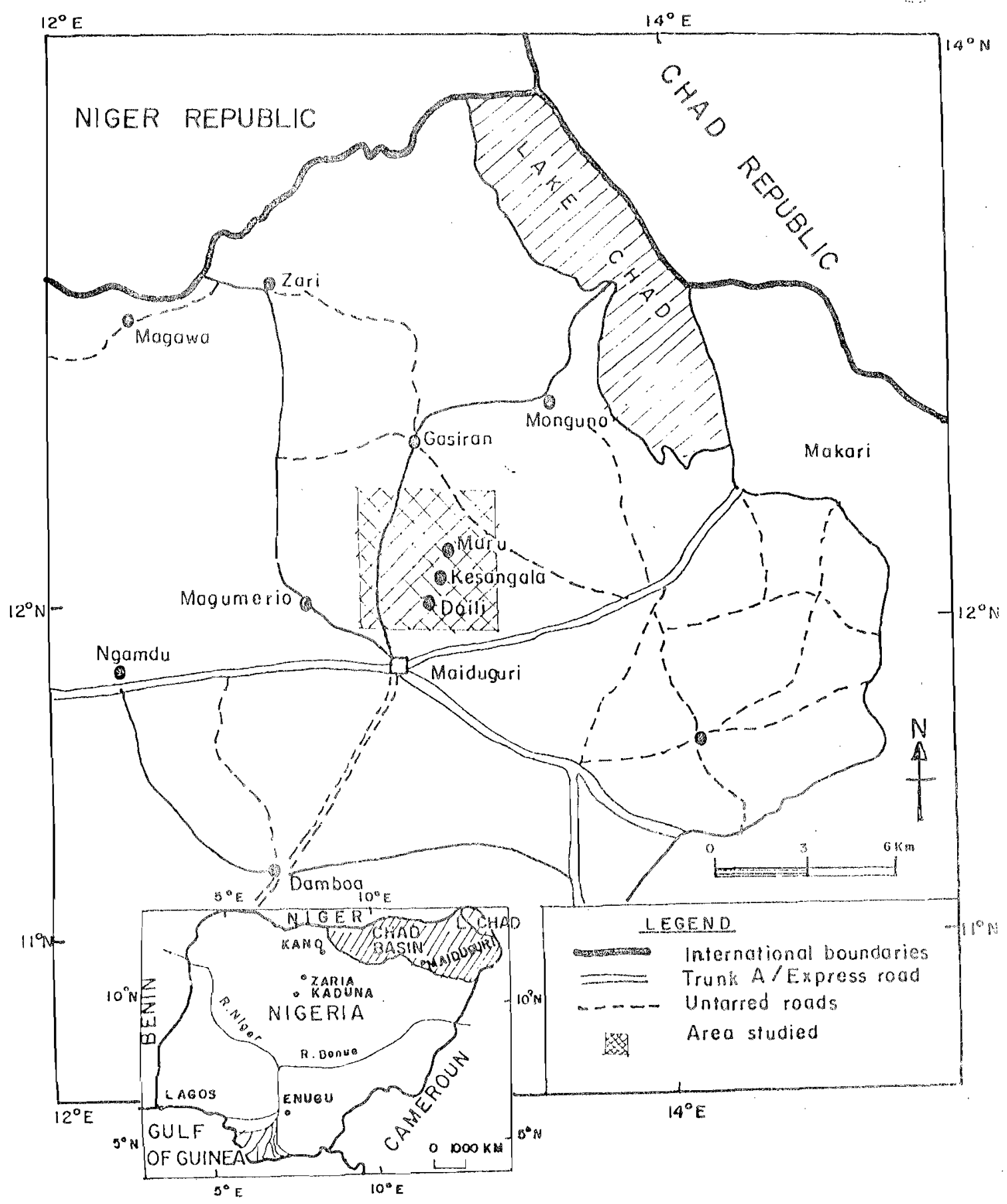

Fig.l'Location map of Doili area of the Chad basin. Insert is a map of Nigerio showing the location of N.E. Nigeria Chad basin. 


\section{GEOLOGY OF THE CHAD BASIN}

The Chad Basin is an epeirogenic drownwarp basin, which occasionally opened to the sea (Petters, 1981). It occupies about $230,000 \mathrm{~km}^{2}$ in Central Sahara and Southern Sudan (Barber, 1965). Its formation was initiated in upper Cretaceous, and shallow marine condition had been prevalent in it. Sedimentation conditions ranged from marine, lacustrine, fluviatile to terrestrial resulting in a stratigraphic sequence subdivisiable into six formations (Table 1). At the end of the Cretaceous, there was a period of folding, during which the Cretaceous strata were folded into a series of anticlines and synclines that were partly eroded, creating an erosional unconformity at the base of the Tertiary deposits.

\section{METHODOLOGY}

Doili area is located within longitudes $12^{\circ}$ $5^{1}$ to $12^{\circ} 15^{1} \mathrm{E}$ and latitudes $13^{\circ} 5^{1}$ to $13^{\circ} 15^{1} \mathrm{~N}$ (Figure 1). The seismic reflection data were acquired in fifteen profiles that range in length from $12.2 \mathrm{~km}$ to $16.25 \mathrm{~km}$ by the Nigerian National Petroleum Corporation (NNPC). The processed data were displayed in black and white wiggle traces as shown in Figures 2 and 3. Structural interpretation involved the identification and tracing of major reflectors on each of the fifteen seismic reflection time sections, and subsequent tying of horizons 2-way traveltimes with adjacent cross lines. Breaks or displacements due to faulting were carefully marked on each section and correlated from one horizon to the other on the same seismic time section and later with time sections of cross lines and adjacent lines within the study area. Two-way traveltimes to each horizon were read at regular intervals of 10 shotpoints $(500 \mathrm{~m})$. Major reflecting horizons were picked within a time range of $0.25 \mathrm{~s}$ to $2.5 \mathrm{~s}$ beyond which no major reflector could be picked.
The Dix (Dix, 1955) equation was used to compute the interval velocities $\left(V_{\text {int }}\right)$ from root mean square velocity $\left(V_{\text {rms }}\right)$. The $V_{\text {rms }}$ was normalized using the function.

$$
V_{\text {rms }}=a t+b \ldots \ldots \ldots \text {... (1) }
$$

Where $t=$ two-way traveltimes to reflector,

$$
a=\text { slope of the graph and }
$$$$
b=\text { intercept on velocity axis ( } y \text {-axis). }
$$

The graphical plot thus involves plotting the values of velocities derived from velocity spectral analysis during stacking on the $\mathrm{Y}$-axis and their corresponding two-way traveltimes on the $X$-axis. This enabled the reading of equivalent $V_{\text {rms }}$ at any given two-way traveltimes of a reflector. The derived interval velocities were used to convert the data from time domain to depth domain in a layer cake model. Lateral variation of the interval velocities was investigated especially around and within the major fold structure seen on some seismic time sections. Depth sections were produced from time sections that enable the visualization of deformation processes in depth domain. Figures 2, 3, and 6 are interpreteci time sections of lines S-26B, D-26 and D-75. Well logs obtained from an exploratory well drilled in the area was analyzed in terms of lithologic sequence, reservoir parameters and fluid content. The location of the exploratory well is shown in Figure 2. These well log responses and deduced lithologies are shown in Figure 5.

\section{RESULTS AND DISCUSSION}

The results of this study will be discussed in three main sections viz: seismic stratigraphy, structural deformation style, evaluation of reservoir parameters, and fluid content of an exploratory well in the area.

\section{(i) SEISMIC STRATIGRAPHY}

Two genetic stratigraphic units are clearly visible on each seismic reflection time section

\begin{tabular}{|c|c|c|}
\hline Age & Formation & Environment \\
\hline Pleislucene & Chad lormalion (unconlormity) & Lacustrine \\
\hline Palcocente & Keri-Keri leormation (unconformily) & Continental \\
\hline Marastrichtian & Gombe Sand stone & Tistuarine-Delaic \\
\hline Senonian & Fika Shale & Marine \\
\hline Turonian & Gongila liomation & Marine-Lsluarine \\
\hline Conomanian & Bima Sandstone (unconformity) & Continental \\
\hline Pre-Cenomanian & Basement complex & \\
\hline
\end{tabular}

Table I: Stratigraphic Sequence in Clad Basin N.E. Nigeria (after Madhe is 1976) 


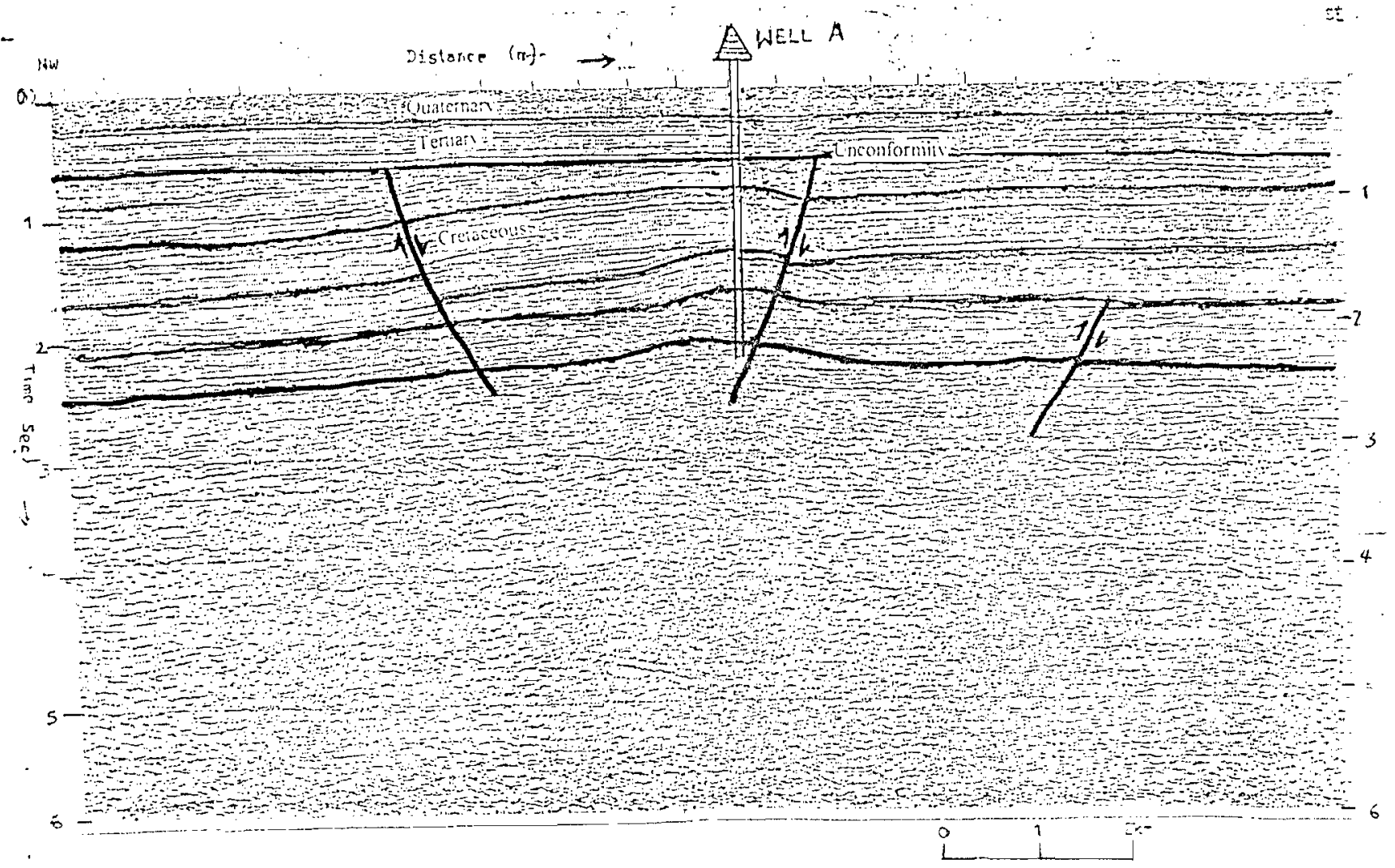

Fig. 2: Interpreted seismic reflection time section of line $\mathrm{S}-26 \mathrm{~B}$, Doili Area, Chad Basin.

from the study area. These stratigraphic units are separated by an unconformity surface as shown in Figures 2 and 3. Generally, five to six seismic horizons are identifiable on the seismic time sections depending on the data quality. The major reflectors are picked within a time range of $0.25 \mathrm{~s}$ to $2.5 \mathrm{~s}$ of the record length (6s)

Two seismic horizons are consistently picked above the unconformity. These appear to correspond to units that have been assigned Quaternary age and Tertiary age (Reyment, 1965, Matheis, 1976) and could conform with the Chad Formation and Keri-Keri Formation respectively based on existing geologic literature (Okosun., 1995). These horizons are relatively flat with almost uniform reflection parameters (reflection continuity and abundance) and exhibit a thickening trend in NE direction (towards the present day Lake Chad). This is indicative of sedimentation in a broad shallow water, low gradient with a relatively uniform low to moderate energy level depositional environment (shallow lacustrine). Absence of divergent, sigmoid or oblique reflection patterns and slump strictures also corroborates this inference. Structurally, they appear to have undergone no faulting or folding. This implies that basin tectonics was tending to or actually reached equilibrium state.
Three to four seismic horizons are picked on seisntic sections below the unconformity plane depending on the data quality/resolution. These seismic horizons generally exhibit abundant parallel reflections, but their continuities have been truncated by faulting and folding. This is an indication of active post-depositional tectonics and the possible arching of the Cretaceous beds by underlying diapiric features. The reflection termination pattern around the folds/anticlines is devoid of onlapping that is characteristic of sedimentation on a paleo-topographic high or relief such as a mound, carbonate reef or preexisting crystalline rock surface. An inference from this is that no such relief existed prior to sedimentation nor was it syn-depositional. The folding of the overlying beds was most probably post-depositional. The seismic horizons below the unconformity plane have generally been assigned Cretaceous age (Reyment, 1965; Matheis, 1976) and no attempt has been made in this work to assign them to the known lithostratigraphic formations of the Chad basin as earlier done for the Cenozoic sediments. This is because the inability to pick reflectors beyond $2.5 \mathrm{~s}$ of the record length should not mean that the basement rocks have been reached. The uncertainty may derive from: 
(i) Seismic data acquisition parameters

(ii) Seismic data processing parameters application of appropriate amplitude decay function /automatic amplitude recovery function

(iii) Penetration of crystalline rocks which often exhibit chaotic/diffraction patterns, although there is a high uncertainty that the basement rocks have been reached.

The lithologic succession of an exploratory well (with a total depth point of $3,250 \mathrm{~m}$ ) deducted from well logs (SP, GR, Sonic and resistivity logs) indicates an alternating sequence of sandstones and shales with gradational lithologies of shaly sand and sandy shale. The exploratory well actually penetrated a faulted block as shown in Figure 2.

\section{STRUCTURAL DEFORMATION STYLE}

Two main structural elements are observable on seismic time sections from the study area. These are faults (normal and reverse), and folds. An analysis of these structural elements is necessary to ascertain their capabilities to trap and retain petroleum. The fault planes have fairly steep gradients and are thought to be due- mainly to tensional stress associated with high angle detachment faulting that is dominantly N.E. trending. The main normal faults trend northeast and are parallel to or approximate the Benue Trough - Chad basin axis (northeast-southwest). Seismic reflection sections that are shot in a northwest-southwest direction clearly show the major normal fault blocks (Figure 2). Subordinate or minor normal faults often cut obliquely across the major fault planes. They could have arisen in response to crustal stretching associated with the main fault blocks. The reverse faults are less common than the normal faults. They are closely associated with the igneous intrusives and could have arisen from underthrusting of the Cretaceous strata by the uprising magma (Figure 3). There is a general absence of strike-slip fault, recumbent fold and a defined regional pattern of folds which would have been indicative of an active regional compressional stress. This is a common feature of rifted basins where compressional stress and shear stress are minimal as compared to the dominant tensional stress. The consequence of a predominantly active tensional stress is crustal

șiv,

$\therefore E$

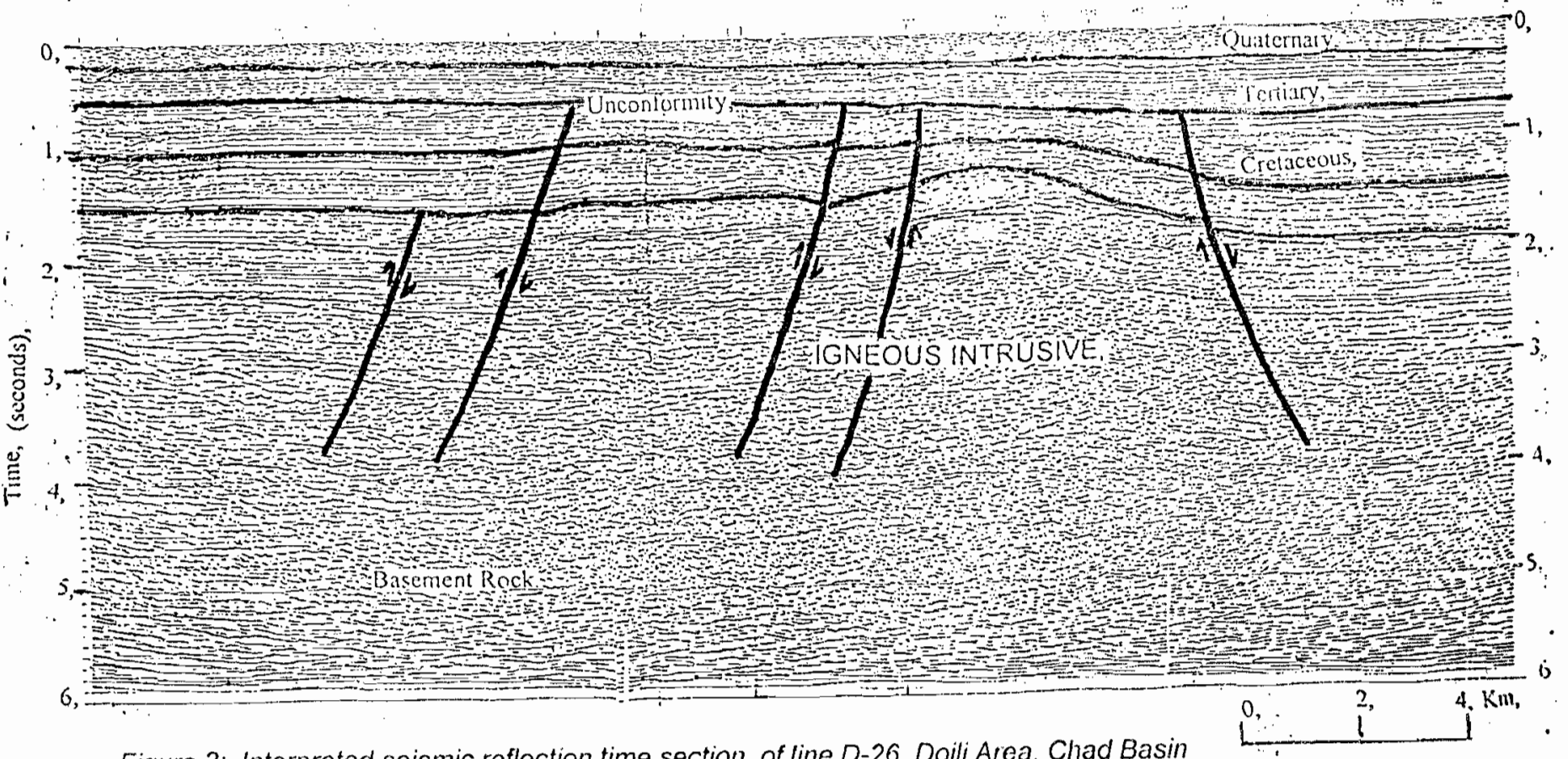

Figure 3: Interpreted seismic reflection time section, of line D-26, Doili Area, Chad Basin 


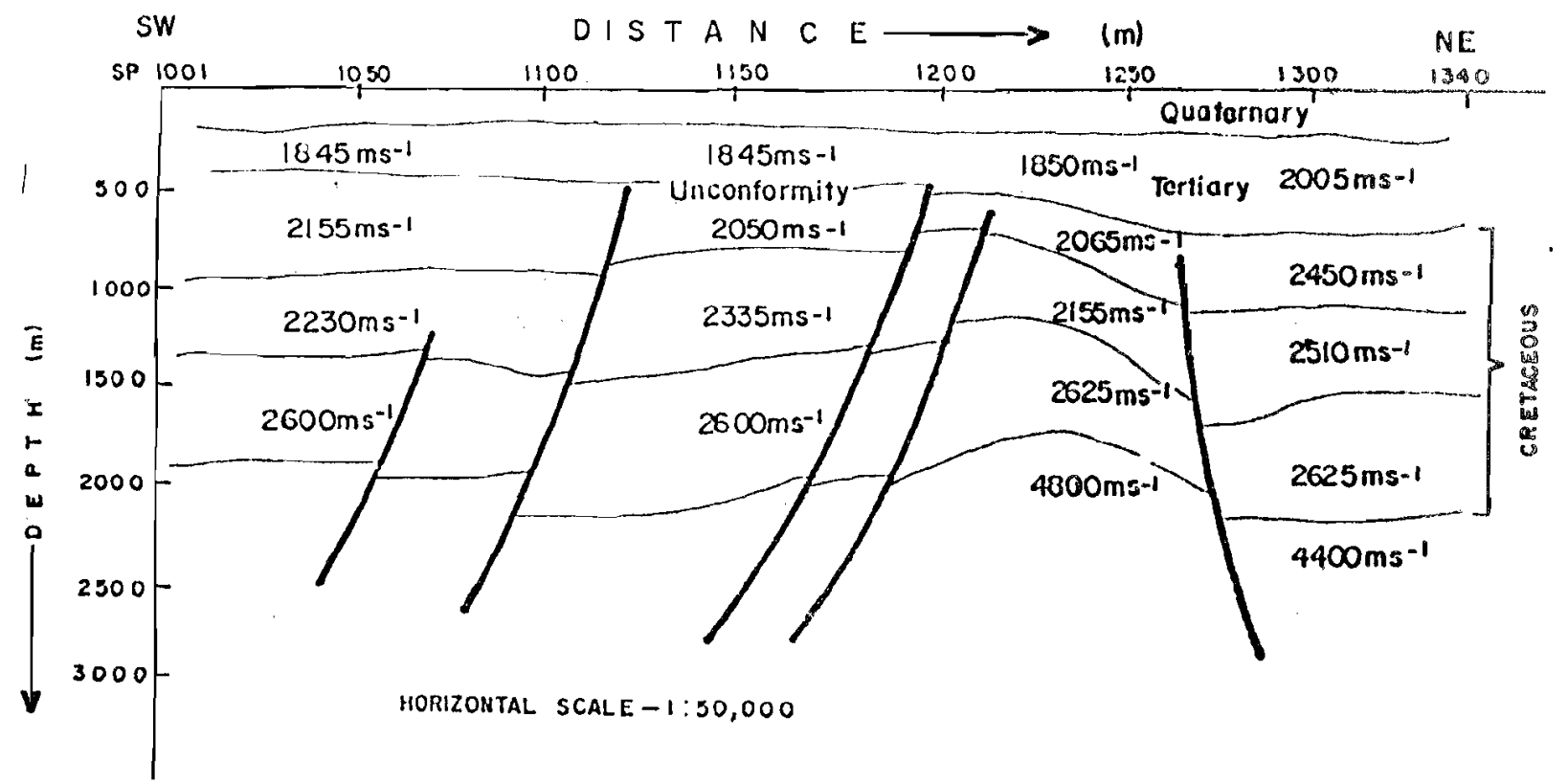

Figure 4: Dopll section with interval velocities and fauls of line D-26. from Doili Arca Chad Basin.

stretching and thinning, development of fractures/ high angle normal faults, rift valley, horst and graben configuration. These would allow the ingress of an epeiric sea with interlayered continental and marine sediments, and upwell of magma to form an oceanic crust (Moore and Twiss, 1995). The above geologic events occur sequentially /in phases, and same is inferred to have occurred in the Chad Basin in the Cretaceous and led to the development of the structural elements common in the basin. However, the Chad Basin being genetically linked with Benue - Trough could not develop into an ocean basin (Genik 1992). Avbovbo et al. (1986) had presented the stages of development of structural features in the Chad basin based on rifting model. However, in this work, it is inferred that the folding of the Cretaceous strata was due mainly to igneous intrusives post-dating their sedimentation. These igneous intrusives are randomly distributed, hence a defined regiorial folding pattern cannot be discerned in this section of the basin. Magmatic intrusions had ceased at the end of the Cretaceous, hence the Cenozoic strata are unaffected. There is thus an erosional surface (unconformity plane) separating the Cenozoic strata from the Cretaceous strata. The stratum immediately below the unconformity plane is unevenly eroded due to its uneven elevation above the base level by the underthrusting magmatic intrusives.

Generally, prospects that are faulted have numerous risks. These risks are due to the following conditions that determine their effectivenoss as traps (Marlan 1990).

(i) The faull plane could provide a conduit for leakage of accumulated hydrocarbon if sediments along it are porous and permeable.

(ii) The fault plane could be an open fracture. (iii) The fault offset could provide lateral seal.

A fault plane will generally behave as transmission open fracture in tensional settings at shallow depthis. Moreover, a fault plane will often transmit fluids in tensional settings with geopressures (Marlan, 1990). A guiding principle is that a fault trace is itself only a representation of the narrow discontinuity where capillary properties, fluid properties and structural dips of the co-joined layer have a probability of being altered. The above conditions have not been adequately documented in the Chad Basin. The possibility of hydrocarbon migrating along the fault planes cannot be ruled out, moreover the displaccment should lead to a placement of impermeable lithologies opposite permeable ones. Thus more data in respect of the above are needed to establish how effective these abundant faults are as fault traps. The faulting pattern in 
this basin is also devoid of growth faults and rollover anticlines, which are the major hydrocarbon traps in the Niger Delta. The arching/folding of the overlying eismic horizons by diapiric features is post-depositional. The existence of several steeply folded structures has variously been attributed to compressional stress or magmatic intrusives (Avbovbo et al. 1986). The seismic expression of the folded structure is due to igneous intrusion (Figure 6).

Interval velocities computed using Dix (Dix, 1955) equation were analysed around and within such a structural element as shown in Figure 4. The range of interval velocities of $2,225 \mathrm{~ms}^{-1}$ to $2,800 \mathrm{~ms}^{-1}$ is within that of siliciclastics. This is however higher within it $\left(4,400 \mathrm{~ms}^{-1}\right.$ to $\left.4,800 \mathrm{~ms}^{-1}\right)$, indicating a different lithology from siliciclastics. The interval velocity distribution pattern around it thus involves higher values along and away from the flanks, lowest around the apex and highest within it. Moreover the beds, even through fairly disrupted, still exhibit some elements of continuity of reflection attributes (abundance and continuity). The leck of reflections (mainly diffraction) within the folded structure (Figure B) is indicative of three likely lithologies viz salt cliapir, carbonate reef or igneous intrusive. Gravity study (Aina, 1988) had indicated randomly distributed intrusives in the basin, hence the igneous intrusion is inferred in this study.

Important deductions from this analysis are:

(i) The folding of the horizons below the unconformity surface was postdepositional, initiated and controlled by igneous intrusive.

(ii) The relatively low interval velocities of horizons around the apex of the folded struclure are attributable to shallow depths due to arching of same beds as velocity generally increases with depth and likely creation of secondary porosity due to folding process.

(iii) The general continuity of reflections over it and lack of diffraction indicate competent lithologies.

(iv) On the basis of time-depth conversion, the intrusive has a minimum depth of $1820 m$ from the present surface.

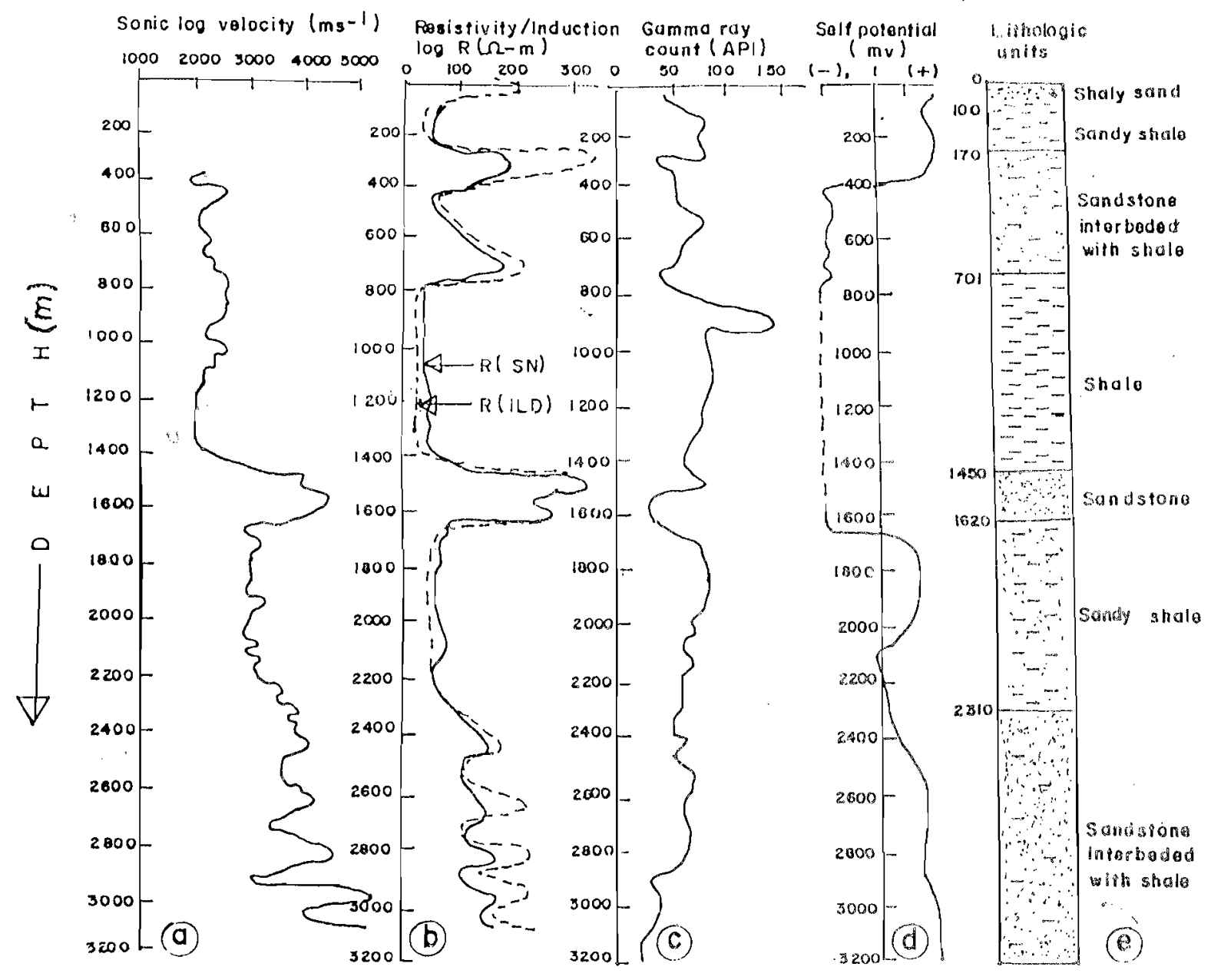

Fig.5 Well log responses and deduced lithologies of an exploratiory well in Dolli area of chad basin. 


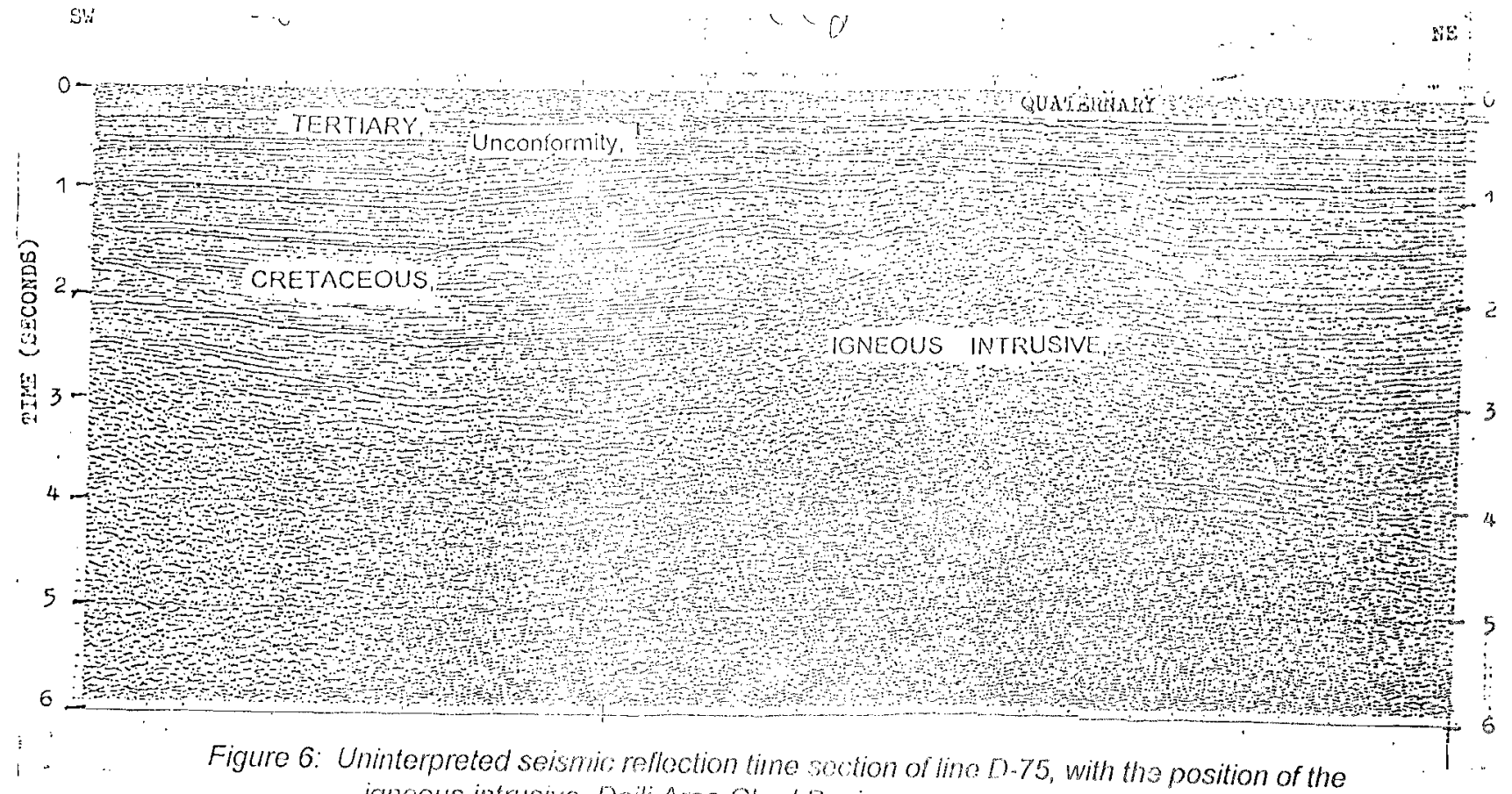

igneous intrusive. Doili Area Chad Basin

(3)

\section{EVALUATION OF RIDEYMOR PARAMETERS AND FLUID OF A WELL}

Two reservoir rocktypes are identifiable in this area based on well logs obiainest in an exploratory well that penetrated a nomal fault block (Figure 2). These are sandstono ank shaly sand. The reservoir units have relatively low porosity of $10.5 \%$ to $20 \%$. This is low comparatively to Niger Delta where a porosity value of $40 \%$ had been reported in some sandstone reservoirs. The formation resistivities; are also very low, generally less than $3005 \% \cdot \mathrm{m}$ with the exception of the depth interval $1450 \mathrm{~m}$ to $1600 \mathrm{~m}$. This conforms with their seismic expressions that are indicative of browd shallow water, low gradient, fairly uniform low to moderate energy level environment. These conditions do not favour proper winnowing of the sediments brought in by fluvial system. The consequence is poor sorting. The hydrocarbon saturation of the cleanest formation penetrated by the exploratory well $(1450 \mathrm{~m}$ to $1600 \mathrm{~m})$ computed yielded a value of $19.06 \%$. This is considered too poor for commercial exploitation.

\section{STRUCTURAL STYLE AND HYDROCARBON PROSPECT OF THE BASIN}

The integrity of the abundant normal and roverse faulis in this basin as structural traps is doubiful. This is particularly so because they are more of iensionaly induced fault systems initiated by displacement within the deep basement rocks. The fault planes are likely to behave as open fractures and provide a passage for hydrocarbons. Though it is generally believed that transmission along fault planes is negligible, on the other hand, if the duration of transmission is considered in terms of hundreds or thousands of years, it becomes highly significant. Another question that needs attention is Does the fault offset a recervoir ber laterally against a sealing bed to provide a trap? The lateral variation in bed ofiset must bo considered. A proper underctanding of the faulting system is necessary to visualize hydrocarbon migration and entrapment in the basin. Conversely in active comprossional seltings, the fault planes would rarely be pathways for hydrocarbon migration as the fault planes would never be open fractures.

The arching/folding of the sediment is post-depositional. The determination of the timing of the arching episode in relation to hydrocarbon migration is necessary to establish whether it is pre-., sygn-, or post - migration. This is crucial if, as inferred in this study, it is due to igneous intrusion. Nwachukwu (1985) pointed out that igneous intrusive posi-dating migration could lead to remigration, cracking, or cutright degradation of 
already accumulated hydrocarbon to carbon or graphite. All of the above point to one fact - that structural interpretation is fraught with risks of drilling dry holes in this basin because the structural trapping elements are adjudged not too effective to prevent petroleum from being disseminated within the formations. Thus detailed seismic facies analysis is needed to locate stratigraphic traps. The stratigraphic barriers could provide the necessary and more favourable conditions for pools of petroleum to accumulate

\section{CONCLUSION AND RECOMMENDATION}

An assessment of structurally related traps in relation to their deformation forces had brought to focus the risks involved in deciding a drilling program based on such trapping elements in the Chad Basin. 2-D seismic reflection time sections from Doili area interpreted in this work reveals a series of normal and reverse faults, and an anticline. Structural style deformation analysis of the fault systems indicates that they are mainly due to tensional stress directed northwest and southeast, and perpendicular to the main axis of Benue Trough - Chad Basin 'northeast southwest). This has created a faulting system with major and minor normal faults. The reverse faults are closely associated with the igneous intrusives, and are thought to be due to underthrusting of the strata by uprising magma. There is a high risk of prospects with tensional stress faults as the fault planes could be open fractures and thus a passage for hydrocarbon. The fold is adjudged due to a diapiric igrieous intrusive that has resulted in arching. of overlying beds. Such igneous intrusives are randomly distributed in the basin. These intrusives have severe effects on accumulated hydrocarbon if they occur post-migration. This is because it could lead to remigration, cracking or reduction to carbon. In view of the above, future drilling programs should search beyond the above structural elements, if successful hydrocarbon exploration is to be achieved in this basin. Structurally controlled traps in the study area have doubtful trapping capability. The effectiveness of these trapping features as petroleum trap is yet to be determined due to inadequate data. It is therefore recommended that stratigraphic interpretation of high quality 3 $\mathrm{D}$ seismic reflection data be carried out to locate subtle stratigraphic traps.

\section{ACKNOWLEDGEMENT}

The author is very grateful to the Nigerian National Petroleum Corporation (NNPC) for providing the seismic sections and well logs for this study.

\section{RlilikRENCES}

Agagu, O.K. and likwewan, C.M., 1980. Potrolewm geolegy ol" Senonian Sediment in Anmmbn Symeline soullicrll Nigeria (Abs). $\triangle A P^{\prime} \mathrm{G}$ Bul. 64, 668p.

Aini, A., 1988. Investigalions of some Now Mognetic

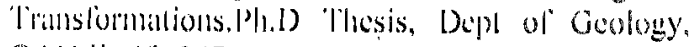
OAU $\|\mathrm{l}-\| \mathrm{li}, 387$ ).

Albechn, 1', and Ourission, G., 1969. Diagenese de liydrocarbures. Gochim at Cosmochin, Act 33, p. $\mid 38-142$.

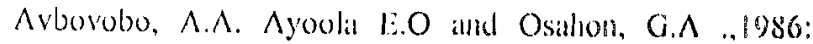
Depositional and strmetural styles in Clat Basin, Nortliastem Nigeria. $\triangle \mathrm{APG}$ Bul. Vol. $70 / \mathrm{No} 2$ p. $1787-1798$.

Barler, W. 1965. Oil and gats developmion in Contral and Soubern $\triangle$ rician. $\triangle A P^{\prime} G$ Bul. 35: 138 - 146.

Dix, C. M., 1955. Scismic Velocities fiom surface measurements. Geoplyysics 20: 68-86.

Ekweozor, C.M. and Okoye, N.V., 1980. Petroleum source bed evaluation of Tertiary Niger Della. AAPG Bul. 64: $\rfloor 25 \mid-1259$.

Genik, G. J., 1992. Regional lianework, structural and petroleum aspects of rili Basins in Niger. Clad and Contral Alicim Republic (C.A:R). Tectonophysics, 213: 169-185.

Mallin, W. D., 1990. Faulting and Hydrocarbon cnlapment. Scismic fnlerpretaltion Series SLG, 2: 57-59.

Matheis, (j., 1976. Slunt review of the Cicology of the Chat Basin in Nigeria, in Geology of Nigeria, Kogbe C.A. (ed), Elizabethan Pub. Coy Lagos Nigeria, p. $289-294$.

Moore, E, M. and Tiviss, R. J., 1995. Tectunics. W.Il. Frceman and Company, New York 415]\%.

Nivachukwu, J. J., 1985. Petroleum Prospect of Bente Trough Nigeria, AAPG Bul. 69: 601-609.

Okosun, E. A., 1995 Review of We Geology of Bornu Basin. Journ. Min. Geol. 31(2): 113-122.

Petters, S.W., 1981. Stratigraphy of Chad and Illumeden basins (Wesl Alirica), Lelogac Geology llelvetate 74: 139-159.

Pelters, S. W. and Ekiveozor, C.W., 1982. Potroleum geology of Benue Trough and Southeastem Chad Basin, Nigeria. $\triangle \triangle P$ P Bul. 60: 1141-1149.

Reyment, R.A., 1965. Aspects of the Geology of Nigeria. University of Ibadan press $145 \mathrm{p}$. 